\title{
Şirindere Gecekondu Sakinlerinin Sosyal Dışlanma Deneyimleri
}

\author{
Z. Aslı Gürel Üçer \\ Gazi Üniversitesi
}

\author{
Seher Özkazanç \\ N. Erbakan Üniversitesi
}

\author{
Neslihan Kokol \\ Gazi Üniversitesi
}

\section{Öz}

1950'li yıllardan itibaren kırdan kente doğru ivme kazanan nüfus hareketleri karşısında özellikle büyük kentlerde, kırdan gelen bireylerin barınma ihtiyactnın karşılanması en önemli sorunlardan biri olmuştur. Kente yeni gelenlerin kentteki mekân mücadelesi gecekondu alanlarmm oluşması ile sonuçlanmış ve böylelikle kentte yer edinilmiştir. Türkiye'de son 50 yılda uygulanan tüm politikalara ră̆men gecekondu, kente yeni gelen dezavantajl gruplar için barınma mekân olmaktadır. Günümüze kadar farklılaşarak süregelen kentte yer edinme mücadelesinin zaman içinde bir sinff mücadelesine evrildiŭi, kente yeni gelmiş, yoksul ve yoksun bireylerin/hane halklarımın çoğu zaman toplumsal yaşamın dışına itildiği görülmektedir. Topluma dâhil olamama, toplumsal ilişkilerden soyutlanma ve toplumla tam olarak bütünleşememe olarak tanımlanan sosyal dışlanma, bu çalışmada "gecekondu sakinleri" bakış açısıyla ele alınmaktadır. Bu kapsamda çalışmanın amacı, Ankara Şirindere Bölgesinde gecekondu alanında yaşayan kişilerin sosyal dişlanma deneyimlerini ortaya koymaktır. Bölgede $1970 l i$ yıllarda başlayan gecekondulaşma hareketi, 2000li yillarda bölgenin çevre yerleşmelerden ve kent bütününden sosyal ve mekânsal olarak ayrışması ile sonuçlanmıştır. Bölge günümüzde alanın fiziki dönüşümü üzerine odaklanan kentsel dönüşüm çahısmalarına konu olmaktadır. Çalışmada Şirindere gecekondu alanının değişim süreci ele alınarak, günümüzdeki gecekondu sakinlerinin sosyoekonomik yapısı ve yaşadıkları sorunlar ortaya konmaktadır. Çalışmanın en önemli sonucu kentin bu ayrışan bölgesindeki gecekondu sakinlerinin kendi içlerinde de sosyo-ekonomik farkllıklar taşıdıkları ve yalnızca kentin diğer kesimleri tarafından değil kendi aralarında da dışlanma deneyimleri yaşadıklarıdır.

Anahtar Kelimeler: Sosyal dışlanma, mekânsal ayrışma, gecekondu, kentin ötekileri, yoksunluk 


\title{
Social Exclusion Experiences of Şirindere Gecekondu Residents
}

\author{
Z. Aslı Gurel Ucer \\ Gazi University
}

\author{
Seher Ozkazanc \\ N. Erbakan University
}

\author{
Neslihan Kokol \\ Gazi University
}

\begin{abstract}
Considering the accelerating population movements from the rural to the urban since 1950s, meeting the housing needs of individuals who migrate-from rural areas has been one of the most important issues, especially in metropolitan cities. The migrants struggle for space has resulted in formation of gecekondu areas, and they have gained a place in the city by this way. Despite all the policies that have been implemented in Turkey for the last 50 years, gecekondu has been a shelter for disadvantaged migrants. It is seen that the struggle for gaining a place in the city that has been maintained up to now in different ways has turned into a class struggle in time, and poor and deprived individual/household migrants have mostly been pushed out of social life. Social exclusion, which is defined as not being able to be included in the society, being isolated from social relationships and failure to completely integrate into the society, is discussed in this study with a perspective of "gecekondu residents". Within this context, the aim of this study is to state the social exclusion experiences of residents of Şirindere Gecekondu District in Ankara, Turkey. The gecekondu movement started in the area in 1970s resulted in the social and spatial isolation of the area from surrounding residential areas and the entire city in 2000s. Nowadays, the area is subject to urban transformation studies that focus on the physical transformation of space. This study presents the socio-economic structure and problems of the gecekondu residents by discussing the development process of Şirindere Gecekondu District. The most important finding of the study was that the gecekondu residents who are living in this isolated area of the city also carried socio-economic varieties, and they also experience social exclusion among themselves.
\end{abstract}

Keywords: Social exclusion, spatial segregation, gecekondu, others of the city, deprivation 


\section{Giriş}

Ülkemizde gecekondulaşma hareketi, ekonomik büyüme ve sanayinin gelişimi ile birlikte ortaya çıkan köyden kente göç sürecinde, özellikle dar gelirlilerin barınma ihtiyaçlarını karşılamak için kısa sürede, ilkel, denetimsiz ve sağlık koşullarından yoksun konut inşa etmesiyle başlamıştır. Genellikle kent çeperlerinde, kamu veya özel kişilerin toprakları üzerinde sahibinin izni olmadan gelişen gecekondu alanları, zamanla kentlerin yalnızca fiziksel değil aynı zamanda ekonomik ve sosyal sorunlarının da mekânı olmuştur. Ancak gecekondu çoğunlukla mevzuat ve mülkiyet sorunu olarak görülmüş ve gecekondu alanlarının yasallaştırılması amacıyla çözümler üretilmiştir. 1966 tarihli 775 sayılı Gecekondu Yasası ve 1984 tarihli 2981 sayılı kanun ile gerçekleşen ıslah imar planlarıyla birlikte gecekondu alanlarının yenilenme süreci başlamıştır. Bu kapsamda bazı gecekondular, 'yapsatçı' girişimciler tarafından üretilen bireysel konutlara ve çok katlı apartmanlara, Toplu Konut İdaresi ve yerel yönetimler aracılığ ile kooperatif ve toplu konutlara dönüşürken (Ataöv ve Osmay, 2007, s.62, 65) bazıları ise 2000'li yıllarda gündeme gelen yasal düzenlemeler kapsamında kentsel dönüşüme uğramıştır. Yarım yüzyılı aşkın bir süredir gecekondu alanlarındaki sorunların çözümü amacıyla gerçekleşen uygulamalar çoğunlukla sadece fiziksel müdahale içermekte, gecekondunun sosyal ve ekonomik boyutu ihmal edilmektedir. Gecekondu alanlarında genellikle yoksul ve yoksun grupların yaşadığı göz önüne alındığında burada bir sınıf probleminin varlığından bahsetmek mümkündür. Gecekondu sakinleri, toplumun gecekonduda yaşamayan "diğer" kesimi tarafından "gecekondulu" olarak adlandırılmakta ve marjinal sektörde veya toplumda kimsenin yapmak istemeyeceği işlerde, düşük ücretlerle istihdam edilen, yoksul, göçmen veya etnik kökenli, suç işleme oranı yüksek bireylerle ilişkilendirilmekte ve ötekileştirilmektedir.

Erman (2004, s.1) gecekondularda yapılan araştırmalar üzerinden gecekondulu kurgusunu dört döneme ayırmaktadır. İlk dönem 1950 ve 60'lı Yıllar: "Köylü Öteki" Olarak Gecekondulu şeklinde tanımlanmakta ve köyden kente yeni gelen, yaşantılarında kırsal alışkanlıklarını devam ettiren hane halklarını temsil etmektedir. Bu yıllarda yapılan akademik çalışmalarda gecekondu halkı homojen bir grup olarak kabul edilmiş, gecekonduluların bir yandan şehirleşirken diğer taraftan da kenti köyleştirdiği vurgulanmıştır. İkincisi 1970'li Yıllar: "Sömürülen/Dezavantajlı Öteki" Ola- 
rak Gecekondulu dönemidir. Bu dönemde gecekondu, gelenekselden modernizme geçiş sürecinden çok kalıcı bir olgu olarak ele alınmaktadır. Gecekondulu ise kapitalizmle birlikte bölüşüm sorunları yaşayan, kente entegre olamamış, kentsel hizmetlerden/firsatlardan yararlanamayan kişi olarak tanımlanmaktadır. Gecekondulular istihdamda yer alsalar bile kentli kesim tarafından sosyo-kültürel boyutta kabul görmemiş, ikinci sınıf vatandaş muamelesine maruz kalmış ve zamanla toplumda “Sakıncalı Öteki" ne dönüştürülmüştür. 1980'li yıllara gelindiğinde ise bu ayrım belirginleşmeye başlamış etnik, mezhep ve cinsiyete bağlı olarak gecekondu mahalleleri yeniden tanımlanmıştır. 1980 ve 90'lı Yillar: “Ötekiler" Olarak Gecekondulu şeklinde ifade edilen üçüncü dönemde haksız kazanç sahipleri ile kent yoksulları olmak üzere yeni gruplar oluşmuştur. Politik kaygılarla getirilen gecekondu afları, gecekondu arazilerini ticari metaya çevirirken arazi mafyaları bu dönemde artmıştır. Bu durum görece daha güçsüz kesimleri (kent yoksullarını) gecekondu yapma sürecinden dışlamış, onları gecekondu kiracılığına yönlendirmiştir. 1990 Sonlarından 2000'lere: "Sakıncalı Öteki Olarak Varoşlu”ya Karşı "Özne Olarak Gecekondulu" şeklinde adlandırılan dördüncü dönemde gecekondular tinercilerin, çetelerin, kapkaççların ve her türlü şiddetin mekânı olarak görülmüş ve gecekondu yerine "varoş" ifadesi kullanılmaya başlanmıştır. Varoşlu ise kentin olanaklarından yararlanırken tüketim estetiğinden ve kent kültüründen yoksun kişiler olarak tanımlanmaktadır. Bu süreçte dünyada olduğu gibi ülkemizde de toplumun avantajlı kesimi korunaklı, dışa kapalı ve güvenlikli konutlarda yaşamını devam ettirirken toplumun diğerleri ile olan ilişkilerini asgari düzeye indirgemektedir (s.3-12).

Gecekondu sakinleri farklı dönemlerde farklı bakış açılarıyla akademik çalışmalarda yerini almış ve her dönemde bu bireylerin/hane halklarının toplumun dışına itildikleri yani sosyal olarak dışlandıkları vurgulanmıştır. Ancak, araştırmalarda "sosyal dışlanma" kavramı biraz daha geç kullanılmış, çünkü kavram görece daha geç tanımlanmıştır. Sosyal dışlanma kavramı ilk olarak Rene Lenoir vasıtasıyla 1974 yılında tartışılmaya başlanmış, Fransız hükümeti ülkede yaşayan insanların onda birinin çeşitli biçimlerde toplumdan dışlandığını belirtmiş̧tir. Dışlanmışlar; zihinsel ve fiziksel engelliler, suç işleyenler, hasta ve bakıma muhtaçlar, yaşlılar, istismar edilen çocuklar, uyuşturucu madde bağımlıları, intihara meyilli insanlar, yalnız ebeveynler, problemli aileler, marjinal, sosyal olmayan (asosyal) insanlar ve diğer sosyal uyumsuzlar olarak tanımlamıştır. Sosyal uyumsuzlar özünde topluma yeniden kazandırıl- 
ması gereken, korunamayan, sosyal olarak dezavantajlı grupları temsil etmektedir (Silver, 1994, s.532). Sosyal dişlanma; yoksulluk, işsizlik, sosyal koruma, eşitsizlik, ayrımcllı gibi temel sosyal politika konularını kapsamakla birlikte çoğu zaman sınıf-altı, yabancılaşma, irtibatsızlık, yoksunluk, marjinallik, bütünleşememe gibi nosyonlarla birlikte kullanılmaktadır (Sapancalı, 2005, s.22).

1980'lerden sonra gecekondu kimliği, tepki ve şiddet barındıran varoş kimliğine dönüşürken kentle "barışık", "gösterişsiz" orta sınıf kültürü de kentin tehlikelerinden, çevre ve görüntü kirliliğinden uzaklaşmak ve alt sınıfla olan mekânsal temasını azaltmak isteyen "dışlayıcı" bir orta sınıf kültürüne dönüşmüştür (Geniş, 2007; s.80). Sosyal yapıdaki değişimin belirtisi olan sosyal dışlanma özellikle büyük kentlerin göç almış, savunmasız ve marjinal bölgelerinde daha fazla hissedilmektedir (Özkazanç, 2016, s.33). Sosyal dışlanma, çok boyutlu bir kavram olması nedeniyle sadece gelir eşitsizliğini, yoksulluğu değil aynı zamanda yaşam koşullarını da belirleyen birçok bileşeni barındırmaktadır. Eğitim, sağlık, barınma, beslenme ve sosyal güvenlik gibi sunulan hizmetlerden yoksunluk biçiminde ortaya çıkan sosyal dışlanma, son yıllarda ülkemizde yaşanan en önemli sosyal sorunlar arasında yer almaktadır. Bu nedenle çalışmanın çatkısı bu kavram üzerinden kurgulanmıştır. Bu çalışma ile Ankara Çiğdem Mahallesi Şirindere mevkiinde bulunan gecekondu bölgesinde yaşanmakta olan yoksulluk, yoksunluk ve çeşitli sosyoekonomik olumsuzluklar ele alınarak söz konusu alanda sosyal dışlanmanın açığa çıkarılması amaçlanmaktadır.

\section{Çiğdem Mahallesi ve Şirindere Gecekondu Bölgesinin Gelişimi}

Şirindere Gecekondu Bölgesi Ankara'nın Çankaya İlçesi'nde, ODTÜ orman arazisi ile Çiğdem Mahallesi sınırları arasında kalan dere yatağında kurulmuştur (bkz. Şekil 1). Bölgenin ve çevresinin 1950li yıllardan itibaren geçirdiği değişim, Şirindere Gecekondu Bölgesi'nin mevcut yapısının anlaşılmasına ışık tutmaktadır. 

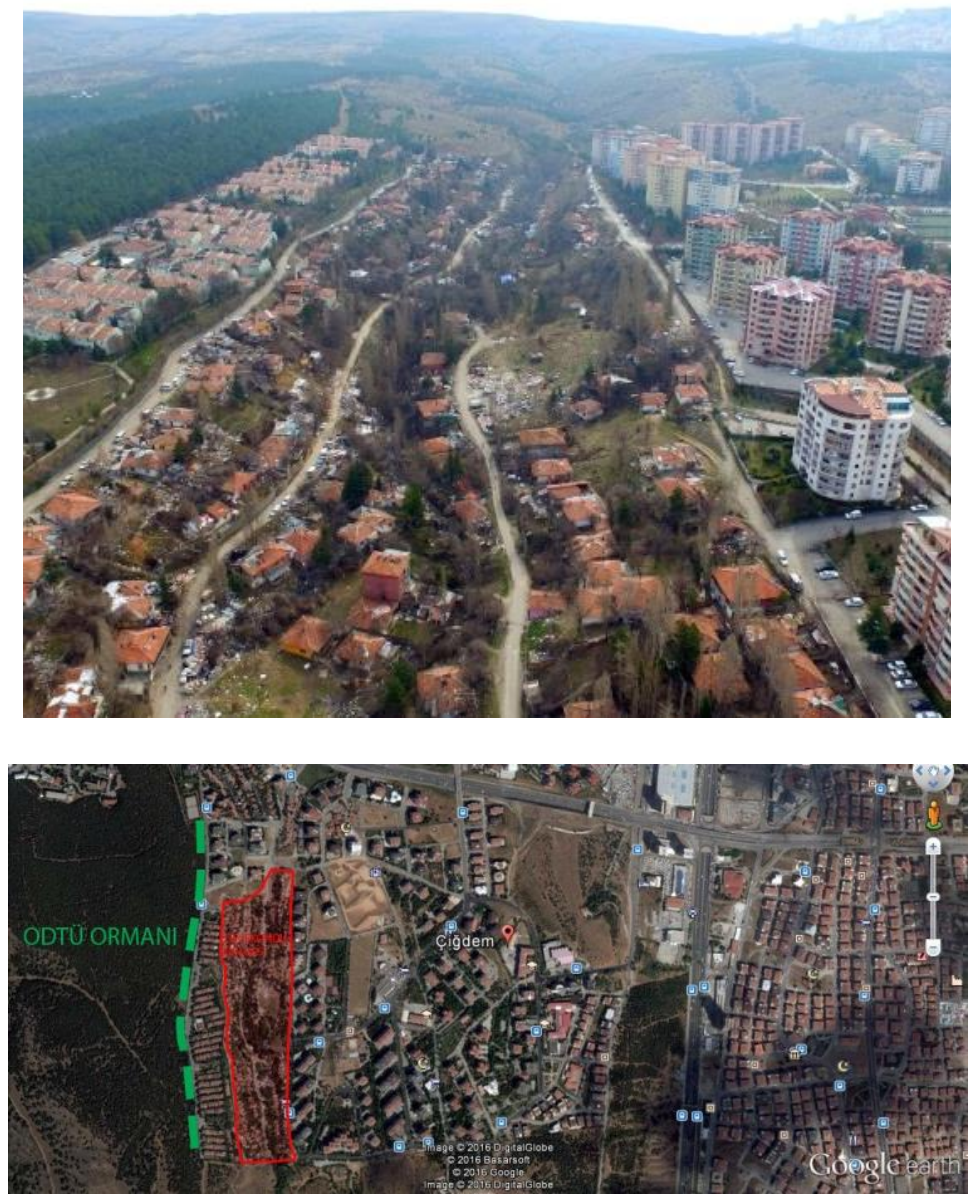

Şekil 1. Şirindere Yerleşim Alanı (Kaynak: https://www.ankara.bel.tr, https://www.google.com.tr/maps)

1950'li yıllarda, bugünkü adıyla Çiğdem Mahallesi'nde Karakusunlar Köyü ve Çiğdem Tepe Gecekonduları olmak üzere iki yerleşim bulunmaktadır. Çiğdem Eğitim, Çevre ve Dayanışma Derneği (Çiğdemim) Çiğdem Mahallesi'nin gelişim sürecini tespit edebilmek amacıyla mahalle sakinleri ile çeşitli görüşmeler gerçekleştirmiştir (Seviğ, 2016). Bu kapsamda 1950lerin ikinci yarısında ailesiyle yöreye göç eden Kemal Akın ile yapılan görüşme mahallenin gelişme süreci hakkında önemli ipuçları vermektedir. Akın, çocukluk dönemini şu şekilde anlatmaktadır:

“1958-59 yillarıydı. Erzurum'un Horasan ilçesinden, ailem göç edince, 3 yaşında geldim bu mahalleye... Amcalarm 1952'de gelmişti. Onların evinde bir yıl 
kaldık sonra kendi evimizi yaptık. Fen Lisesi bitişiğinde 3-4 ev vardık. Amcamlar ve bir yakın köylümüz, hepsi o. Bir de su kuyumuz vardı."

Bölgeye daha sonraki yıllarda Yenidoğan ve Altındağ'dan da gelenlerin olduğunu, yerleşenlerin süt hayvancılığı yaparak hayatlarını idame ettirdiğini belirten Akın şöyle devam etmektedir:

"1960 İhtilali oldu. Uçaklar Harp Okulu üstünde uçarken, tam o strada mahallenin adı kondu. 5 yaşındayım, ben de onları dinliyordum. Tevfik amcam, 'buranın adı Çiğdem olsun' dedi. Çeorede çok çiğdem çiçeği yetişiyordu, ondan dolayı..."

1961 yılında Ankara Fen Lisesi'nin inşasına başlanmıştır. Fen Lisesi'nin açıldığ 1 tarihlerde okulun kuzeyindeki yerleşim bölgesi belediye sinırları içinde değildir, Karakusunlar Köyü'ne bağlı olan yerleşme 1977'de belediye sınırları içine alınmıştır. Karakusunlar'da yerleşim desenindeki değişim aslında 1970'lerden sonra hız kazanmıştır. ODTÜ arazisinin istimlak edildiği dönemde üniversite alanında kalan Yalıncak Köyü'nden bazı aileler Karakusunlar Köyü'ne yerleşmiştir. Yalıncak Köyü istimlak sırasında yaklaşık 350 kişinin barındığı bir yerleşim yeridir ve yöre halkı Karakusunlular'da olduğu gibi hayvancılıkla geçinmektedir. İstimlak yapılırken ayn zamanda artan rant nedeniyle mera alanlarına kooperatifler tarafından konutlar yapılmaya başlanmış, böylece günümüzde ODTÜ evleri ve ODTÜ Çamlık Sitesi olarak adlandırılan konut alanları ortaya çıkmıştır (Seviğ, 2016)(bkz. Şekil 2).
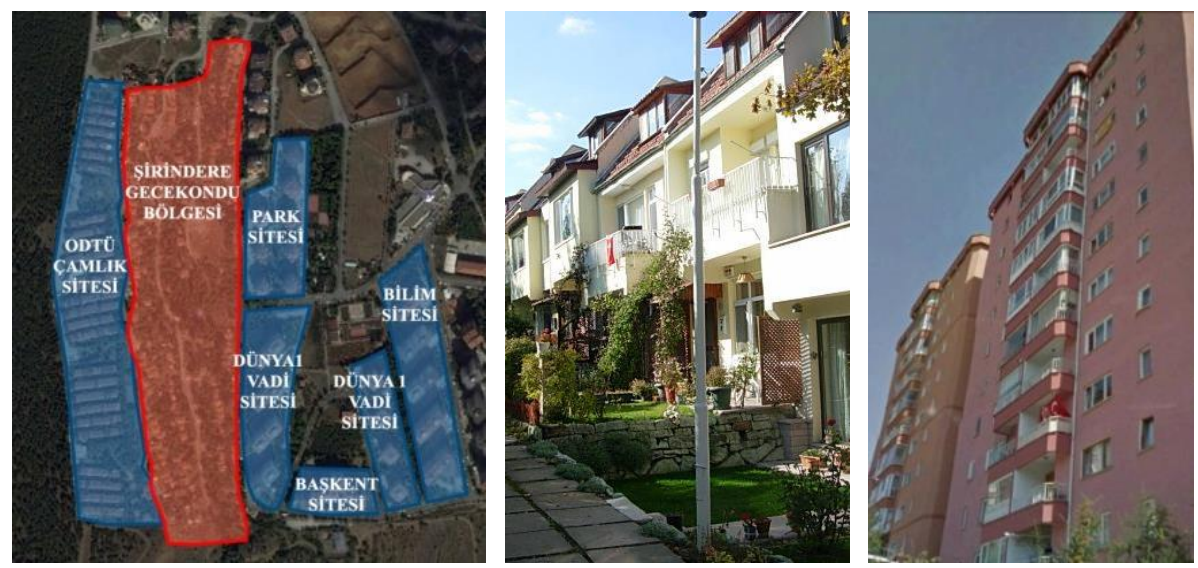

Şekil 2. Şirindere Gecekondu Bölgesi ve Çevresindeki Konut Siteleri (Kaynak: earth.google.com), Odtü Çamlık Sitesi (Kaynak: http://www.odtu-camlik.org) ve Dünya 1 Vadi Sitesi 
1970'lerin ikinci yarısında Türkiye İşçi Sendikaları Konfederasyonu ve buna bağlı bazı sendikaların üye ve yöneticilerinin girişimiyle kurulan yapı kooperatifi de arazi edinme yoluyla inşaata başlamıştır. Bölgede başlayan bu çok katlı yapılaşmanın inşasında çalışmak üzere mahalleye işçi akını yaşanmıştır. Büyük bölümü Erzurum'dan gelen inşaat iş̧̧ileri barınma ihtiyaçlarını en ucuz şekilde karşılamak ve inşaatlarda çalışmak amacıyla bu yeni şantiyelere en yakın alan olan Şirindere Vadisi'ni tercih etmiş, köy muhtarlığının desteğiyle kendi konutlarını yapmaya başlamıştır. Bu nüfus değişiminin sonucunda Şirindere Vadisi'nde ilk gecekondulaşma hareketi başlamıştır (Seviğ, 2016).

Vadide 1970'li yıllardan itibaren başlayan gecekondulaşma hareketi gün geçtikçe ivme kazanmış, maddi olarak yoksunluk çeken bireylerin bu alana yerleşmesi, kendileriyle aynı gelir seviyesine sahip insanlarla bir arada yaşamalarını sağlamış, kentin ötekileri bir anlamda bütünleşmiştir. Şirindere Vadisi'nin hemen doğusunda yer alan Dünya 1 Vadi Sitesi'nin ardından Park ve Başkent Sitelerinin inşasına başlanmış, site şeklinde ilerleyen konut inşaatları 1991 yılına kadar hız kesmeden devam etmiştir (bkz. Şekil 2). Ancak yüksek katlı, güvenlikli/korunaklı bu siteler gecekondularla taban tabana zit bir morfoloji sergilemektedir. O yıllarda prestij/lüks olarak adlandırılan bu konutları yüksek gelir seviyesine sahip kentin varsılları tercih etmektedir. Bu yapısal değişim ile birlikte ortaya çıkan yeni kullanıcı profili ise Şirindere Gecekondu Bölgesi'nde sosyal dışlanmanın oluşmasına zemin hazırlamıştır.

1990'lı yıllara kadar artarak varlığını devam ettiren Şirindere Gecekondu Bölgesi 2000'li yıllara gelindiğinde Çiğdem Mahallesi yerleşiminden hem sosyolojik hem de mekânsal olarak tamamen kopmuştur. Bu ayrışmış mekân 2005 yılında kentsel dönüşüm alanı ilan edilmiş ancak “6306 sayılı Afet Riski Altındaki Alanların Dönüştürülmesi Hakkındaki Kanun" hükümlerince jeolojik risk barındırması sebebiyle dönüşüm kararı iptal edilmiştir. Şirindere Gecekondu Bölgesi'nin riskli alan ilan edilmesinin ardından çoğu ev sahibi gecekondusunu terk etmiştir. Bu tahliye ile birlikte alandaki boş konutlarda yeni kullanıcılar barınmaya başlamıştır.

\section{Şirindere Gecekondu Bölgesinde Sosyal Dışlanma}

Şirindere Gecekondu Bölgesi'nde yaşanan/yaşanabilecek sosyal gerilimlerin ve dışlanmanın tespit edilebilmesi ve bölgenin dışlanma riskinin 
ortaya konabilmesi için mahalle sakinlerinin sosyo-demografik ve ekonomik yapısı irdelenerek sosyal dışlanmanın nedenleri ve boyutları açığa çıkarılmaya çalışılmıştır. Bu bağlamda anket ve derinlemesine görüşme tekniğinden yararlanılmış, alandaki 150 gecekondudan (252 gecekondu bulunan alanda çalışmanın yapıldığı sırada 150 ailenin ikamet ettiği tespit edilmiştir) rastgele örneklem yöntemiyle seçilen 30 hanehalkı ile anket, Çiğdemim Derneği üyeleri ve mahalle sakinleri ${ }^{1}$ ile derinlemesine görüşme çalışması gerçekleştirilmiştir. Anketlerde bireylerin demografik ve hanehalkı bilgileri, konut ve yaşam çevresi, çalışma ve gelir düzeyi, göç, eğitim ve sağlık durumları, sosyal algılar ve kent içi hareketlilik düzeylerine ilişkin 37 soru yer almaktadır.

Kentsel dönüşüm çalışmaları sürecinde sahipleri tarafından boşaltılan gecekondular kente yeni göç eden ve enformel sektörde çalışan bireyler tarafından kullanılmaya başlanmıştır. Bu nedenle katılımcıların sadece \%37'sinin kendi mülkü olan gecekonduda ikamet ettiği görülmektedir. Geriye kalan \%63'lük bir kesimin ise \%75'inin kira ödediği, \%25'inin ise ev sahibine ulaşamadığı gerekçesiyle herhangi bir kira ödemediği tespit edilmiştir. Mülk sahibi olmayanların nerdeyse tamamını son altı yıl içinde Ankara'ya göç eden Adıyamanlı hanehalkları oluşturmaktadır.

Çalışmada alanın değişim sürecinin bir sonucu olarak (sosyodemografik ve ekonomik bulgular ile yapılan görüşmeler de dikkate alındığında) Şirindere'de iki farklı hanehalkı profilinin olduğu tespit edilmiştir (bu durum sosyal dışlanma düzeylerini ve deneyimlerini anlaşılabilir kılmakta yardımcı olmuştur). Bunların ilki 1970'li yıllarda alana yerleşen, genellikle oturduğu gecekondunun sahibi, diğerlerine nazaran daha düzenli işe ve gelire sahip bireylerden oluşan hanehalklarını karakterize etmekte ve çalışmada Profil 1 olarak adlandırılmaktadır. İkincisi ise Şirindere'nin riskli alan ilan edilmesiyle birlikte terk edilen gecekondulara yerleşen, düzenli bir işe ve gelire sahip olmayan hanehalklarını karakterize etmekte ve çalışmada Profil 2 olarak adlandırılmaktadır.

\section{Sosyo-demografik Yapı}

Katılımcıların cinsiyet dağılımları incelendiğinde \%56'sının kadın, \%44'ünün erkek, yaş ortalamasının ise erkekler için 36, kadınlar için 28 olduğu tespit edilmiştir. Katılımcıların hane halklarındaki yaş ortalaması

\footnotetext{
${ }^{1}$ Alanda Suriye'deki iç savaş nedeniyle Türkiye'ye gelen göçmenler de yaşamaktadır. Ancak bu hane halkları ile anket / derinlemesine görüşme gerçekleştirilememiştir.
} 
ise 18,6 'dır. Örneklemin \%87'sinin evli hane halklarından oluştuğu, evliliklerin erken yaşta yapıldığı ve çocuk sayısının yüksek olduğu (üç ve üzeri) yapılan görüşmelerde açığa çıkmıştır. Örneklemde tek başına yaşayan ya da akrabalık ilişkisi bulunmayan bireylerin bir araya gelmesiyle oluşan haneler Profil 2'de yoğunlaşmaktadır. Örneklemin ortalama hanehalkı büyüklüğü 6,7 hanedeki ortalama aile sayısı ise 2,1'dir. Ortalama hanehalkı büyüklügünün yüksek olması ve hanede 1 'den fazla ailenin birlikte yaşaması yoksulluğun bir göstergesi olmakla birlikte, gelirin paylaşımı ve dolayısıyla bölüşüm kaynaklı sosyal dışlanma riskini de artırmaktadır.

Örneklemin eğitim düzeyi incelendiğinde \%21'inin okuma ve yazma bilmediği, \%36'sının sadece okur-yazar olduğu, \%32'sinin ilkokul mezunu olduğu görülmektedir. Katılımcilara alanda eğitim seviyesinin bu denli düşük olmasının sebepleri sorulduğunda erkek katılımcılar maddi durumlarındaki yetersizlik nedeniyle erken yaşta iş hayatına atılmak zorunda oldukları için okula gidemediklerini, kadın katılımcılar ise ev işlerine yardım ya da erken yaşta gerçekleştirilen evlilikler nedeniyle okula devam edemediklerini belirtmektedir.

Çocukların okula gitmeme nedenleri incelendiğinde katılımcıların \%58'i çocuklarının çalışarak aile ekonomisine katkıda bulunmak zorunda olduğunu belirtmektedir. Ne yazık ki Şirindere'de çocukların büyük bir kısmı okula devam edememektedir (bkz. Şekil 3) Alan çalışması kapsamında gerçekleştirilen derinlemesine görüşmelerde bir çocuk bu durumu şu şekilde aktarmaktadır:

“Şu an 13 yaşındayım, Adıyaman'dayken okula gidiyordum çünkü o zaman babam cam ustalı̆̆l yapıyordu. Daha sonra Suriyeliler geldi ve babamı işten çıkardılar, memlekette iş bulamadı biz de Ankara'ya geldik. Buradaki gecekondular boş olduğu için kira ödememiz gerekmiyordu buraya yerleştik. Babam, ağabeyim ve ben hepimiz kâğıt topluyoruz. Ağabeyim de ben de kâğıt toplamak zorundayız çünkü babamın tek başına kazandığı para evimize yeterli olmuyor. Çalıştığım için okula gidemiyorum kardeşlerim de masraflı olduğu için okula gidemiyorlar, paramız olsa okula gitmemizi çok isterdim. Ben günümü çalışarak geçiriyorum kardeşlerim ise sokakta oyun oynayarak geçiriyor..." 

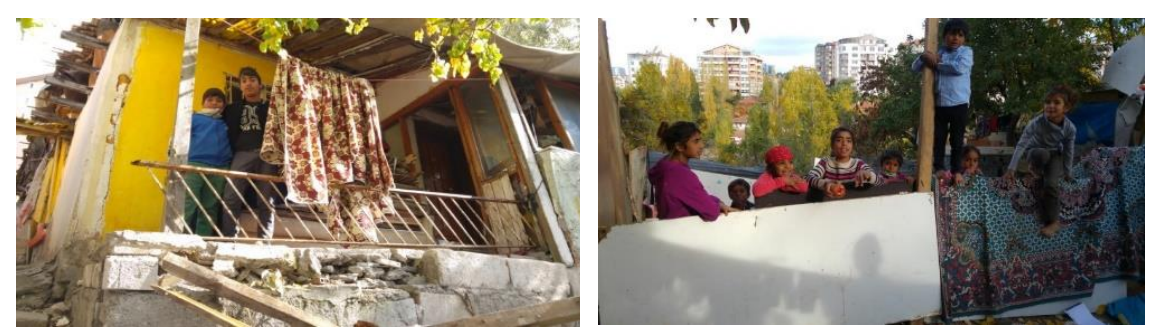

Şekil 3. Şirindere' de Okula Gidemeyen Çocuklar

Katılımcılara eğitim gören çocuklarının eğitim hayatlarında (okullarında) karşılaştıkları sorunlar sorulduğunda \%64'ü maddi imkânsızlık yanıtını vermiştir. Yoksulluk dolayısıyla kıyafet ve okul araç gereçleri tam anlamıyla karşılanamayan çocuklar ya diğer çocukların müstebitliği ya da alay edilme korkusuyla kendilerini yaşıtlarından soyutlamaya başlamıştır.

Katılımcılara "Herhangi bir iş/sağllk sigortanız var mı?" sorusu yöneltildiğinde \%38'inin bu imkâna sahip olmadığı (Profil 2'de sigortalı bireyler yok denecek kadar azdır) tespit edilmiştir. Bu durum kayıt dışı olarak günü birlik işlerde çalıştırılmalarından kaynaklanmaktadır. "Herhangi bir sağlık sigortam yok" cevabını veren bireylere "Sağglı sorunlarınızı nasıl çözüyorsunuz?" sorusu sorulduğunda ise \%54'ünün "geleneksel yöntemlerle" cevabını verdiği, sağlık hizmetlerinden yoksun oldukları görülmüştür.

\section{Çalışma Durumu ve Gelir Düzeyi}

Katılımcıların istihdam durumuna ilişkin analizler yapıldığında örneklemin \%35'inin çalıştı ̆̆ ${ }_{1}$; 28 'inin ev hanımı, \%20'sinin iş aramakta ve $\% 17$ 'sinin emekli olduğu tespit edilmiştir. İstihdama katılanların ise \%82'sinin enformel sektörlerde çalıştığı (kâğıt toplayıcılığı, gündelikçilik vb.) görülmektedir. Nitekim eğitim düzeyi oldukça düşük olan örneklemde istihdamın enformel sektöre kayması beklenen bir sonuçtur. Bu bireylerin kente göç ederek geldikleri de düşünüldügünde bu durum perçinlenmektedir. Nitekim "Daha önce şehir dışında yaşadınız mi/göç ettiniz mi?" sorusuna örneklemin \%56'sı evet cevabını vermiştir. Göç edenlerin büyük bir kısmı 2011 yılı sonrasında Suriyeli mültecilerin yaşadıkları kentlere yerleşerek ucuz iş gücü oluşturması nedeniyle mevcut işlerini kaybettiklerini, yeni iş bulamadıklarını ve mecburen Ankara'ya (büyükşehirlere) geldiklerini ifade etmektedir. Kente yeni gelen bu göçmenler yaşamlarını oldukça çok zor şartlar altında devam ettirmektedir. Son 
beş yıldır göç edenler arasında Adıyamanlılar çoğunluğu oluşturmaktadir.

Örneklemin gelir ortalamalarına bakıldığında \%35'inin 1000-1500 TL, $\% 32$ 'sinin 500-750 TL, \%22'sinin 300-500 TL ve \%10'unun 500 TL ve daha az gelir elde ettiği görülmektedir. Ancak örneklemde gelirler her ay farklılık göstermekte, bireylerin \%77'si (bu oran Profil 2'de artmaktadır) aylık düzenli bir gelire sahip ol(a)madığını ifade etmektedir. Görüldüğü gibi Şirintepe'de yaşayan hane halkları asgari ücretin altında bir gelir ile yaşamlarını devam ettirmektedir. Bu denli düşük gelir seviyesine sahip oldukları için barınma, yeme-içme gibi temel ihtiyaçlarını dahi karşılamakta zorlanmakta, bu yüzden eğitim, sağlik ve sosyo-kültürel aktiviteler için gerekli olan harcamaları gerçekleştirememektedirler. Ayrıca örneklemdeki bireylerin zorunlu ihtiyaçlarını karşılayabilmek adına akraba veya arkadaşlarından borç para aldıkları saptanmış, katılımcıların \%35'i hep borçla yaşadığını, \%32'si sık sık borçla yaşadığını, \%27'si bazen borç aldığını belirtmiştir.

\section{Yaşam Alanlaru ve Kentsel Hizmetlere Katılım}

Alanda tanımlanan Profil 1 ve Profil 2'nin yalnızca sosyo-ekonomik yönden değil aynı zamanda mekânsal olarak da farklılaştığı tespit edilmiştir. Nitekim çalışmada, kentin bu çöküntü bölgesinde bile her iki alt gelir grubunun yaşam alanları, konutlarının dış cepheleri, bahçe bakımları vb. mekânsal farklılıklar saptanmıştır. Profil 1'in Profil 2'ye göre (görece!) daha düzenli ve fazla bir gelire sahip olması konut bakımı için gerekli harcamaları doğrudan etkilemektedir. Ayrıca Profil 2'de yaygın olarak kâğıt toplayıcılığı yapılması ve toplanan ürünlerin bahçelerde depolanması konutları daha da bakımsız kılmaktadır (bkz. Şekil 4).
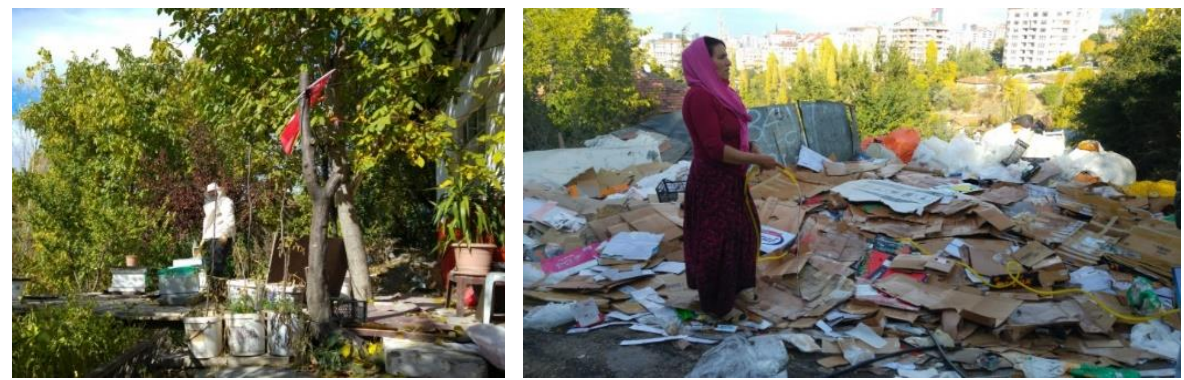

Şekil 4. Profil 1 (solda) ve Profil 2 (sağda) Yaşam Alanları 
Ancak temizlik ve bakım yönünden farklılaşan bu konutların yapı kalitesi ve nitelik açısından benzer olduğu görülmektedir. Alandaki tüm gecekondular tek katlı, yığma yapılardır ve hepsinin kendine ait bir bahçesi bulunmaktadır. Konutlarda kullanılan ısıtma sistemi ise sobadır. Oldukça düşük standartlı bu konutlardan duyulan memnuniyet oranları incelendiğinde Profil 1'in gecekondularından memnun olduğu ancak Profil 2'nin konforsuzluk (yetersiz oda sayısı, rutubet, yalıtım olmaması, su ve kanalizasyon sistemi eksiklikleri vb.) nedeniyle şikâyet ettikleri görülmektedir. Bu durum Profil 1'de ev sahipliği oranının artması ile ilişkilendirilebilir; ev sahiplerinin kira ödememesi, konutu az da olsa iyileştirebilecek, tamirat-tadilat edebilecek maddi imkânlara sahip olmas1 konuttan duyulan memnuniyeti artırmaktadır. Örnekleme "Başka bir yerde oturma imkânını olsaydı konutunuzun nerede olmasını isterdiniz?" sorusu yöneltildiğinde ise katılımcılar yine Çiğdem Mahallesi'nde fakat lüks konutlarda yaşamak istediklerini belirtmiştir. Nitekim benzer mekânlarda oldukça farklı hayatlar yaşanmaktadır.

$\mathrm{Bu}$ başlıktaki bir diğer konu ise kentsel hayata ve hizmetlere katılım düzeylerine ilişkindir. Bireylere yönlendirilen "Kent içi aktivitelerin (okul, alışveriş, rekreasyon vb.) hangilerine, hangi ulaşım türünü kullanarak erişiyorsunuz?" sorusuna katılımclların tümü "hepsine yürüyerek gidiyorum" cevabını vermiştir. Kentsel aktivitelerin yürüme mesafesinde gerçekleştirilmesi Şirindere gecekondu bölgesinde yaşayan bireylerin yaşam döngüsünün Çiğdem Mahallesi üzerine kurulu olduğunu göstermektedir. Eğitim alabilen çocuklar mahalle okuluna gitmekte, ebeveynleri kâğıt toplayıcılık işini Çiğdem Mahallesi, 100. Yıl Mahallesi ve Çukurambar Mahallesi gibi çevre mahalleleri dolaşarak gerçekleştirmektedir. Katılımcıların rekreasyon alanı olarak mahalle parklarını tercih ettikleri, para gerektiren aktiviteler yapamadıkları ve yol ücreti ödememek için kent merkezine gitmedikleri belirlenmiştir. Alışveriş ihtiyaçlarını ise gecekondularının çok yakınında bulunun bir büfeden karşılamaktadırlar. Bu bulgulardan yola çıkarak kentin çöküntü alanında yaşayan bu bireylerin kentte yaşamalarına rağmen kentin sunduğu imkânlardan yararlanamadıkları ve dolayısıyla kentsel yaşama dâhil olamadıklarını söylemek yanlış olmayacaktır. 


\section{Çiğdem Mahallesi Sakinleri ve Ötekiler: Şirindere Gecekondu Sakinleri²}

Şirindere Gecekondu Bölgesi'nde yaşayanların önemli bir bölümü kente yeni gelen göçmen, yoksul, işsiz, eğitim imkanlarından yoksun, etnik kökenli vb. "marjinal" gruplardan oluşmakta ve Çiğdem Mahallesi sakinleri tarafından ötekileştirilmektedir. Nitekim benzer mekândaki bu iki sosyal grubun demografik, kültürel, ekonomik düzeyleri ile yaşam standartları oldukça farklılaşmaktadır. Bu farklılaşma sosyal dışlanmayı beraberinde getirmiştir. Yapılan görüşmelerde Çiğdem Mahallesi sakinleri sosyal dışlanmaya sebep olmadıklarını, mahallede eyleme dönüşen hiçbir vukuatın (şiddet, gasp vb.) gerçekleşmediğini ve bu durumun sadece yoksullukla ilişkili olduğunu belirtmektedir. Oysa daha detaylı sorularda eğitim, sağlık, barınma, rekreasyon gibi birçok kentsel hizmet alanında ve hatta kamusal mekanlarda bile kentteki "ötekiler" ile kesişmek istemediklerini açıç̧a ifade etmektedirler. Bir yandan vicdani duygularla bu insanlara, özellikle çocuklara yardım etme isteği ile diğer yandan güvenlik kaygıları çatışmakta, bu sebeple çoğu mahalle sakini Şirindere'yi görünmez kılmayı tercih etmektedir. Kendi konutları ile gecekondular arasındaki dikenli teller bu gör(ün)mezliğin en somut halidir.
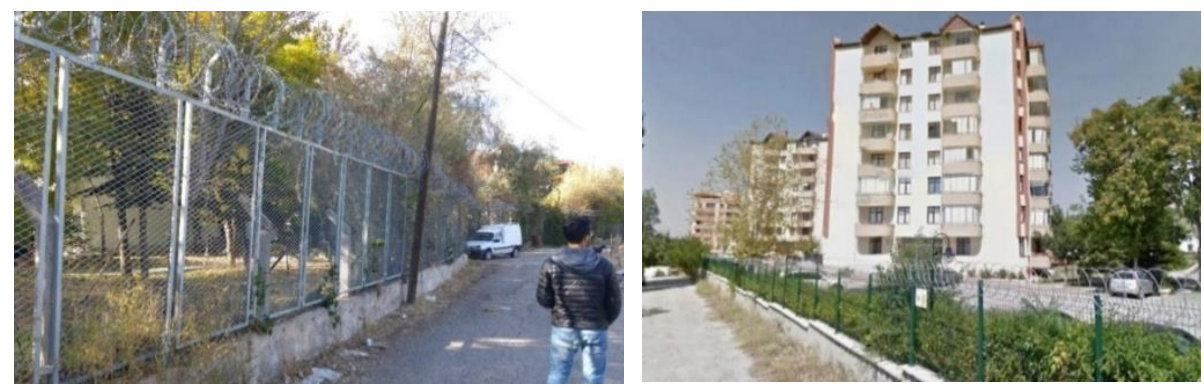

Şekil 5. Gecekondu Alanıyla Diğer Konutların Mekânsal Ayrışması

Çiğdem Mahallesi sakinleri tarafından farkında olmadan gerçekleştirilen görmezlik hali, gecekondu sakinlerinin (Profil 2'nin tamamı, Profil 1'in bir kısmı) kendilerini psikolojik ve sosyal olarak dışlanmış hissetmelerine neden olmaktadır. Özellikle kadınlar Çiğdem Mahallesi sakinlerince ev işleri ve temizliğe yardıma kabul edilmediklerini, rekreasyon alanlarında çocuklarının yalnızca kendi mahallesinden çocuklarla oynadığını ve diğer annelerin genellikle kendilerinden uzakta durduğunu

\footnotetext{
${ }^{2} \mathrm{Bu}$ başlıktaki saptamalar derinlemesine görüşmelerden faydalanılarak oluşturulmuştur.
} 
belirterek ayrıştırıldıklarını, dışlandıklarını ifade etmektedirler. Erman'ın (2004, s.12) ifade ettiği gibi yeni gecekondulular kent seçkinleri tarafından yoz, dejenere, varoş kültürü şeklinde tanımlanmıştır. Bu tanımlama Çiğdem Mahallesi sakinlerince açıkça ifade edilememekle birlikte yap1lan derinlemesine görüşmelerde kültürlerinin ayrışması, kırsal niteliklerin devam ettirilmesi, çocuklarına kötü örnek olma durumu, gecekonduların çevreye uyumsuz görüntüsü, yeniden yapılacak konut alanlarına adaptasyon sorunu yaşanacağı gibi ifadelerle üstü kapalı olarak açığa çıkmaktadır.

\section{Değerlendirme ve Sonuç}

Çiğdem Mahallesi Şirindere Gecekondu Bölgesi'ne odaklanılan bu çalışma ile bölgede yaşayan bireylerin çeşitli nedenlerle ve farklı boyutlarıyla sosyal dışlanmayı deneyimledikleri görülmektedir. Yapılan anket çalışması sonuçlarına göre gecekondu bölgesinde sosyal kırılganlığı artıran birçok etmen tespit edilmiştir. Bunlar göç, genç nüfus (örneklem yaş ortalaması 18,6'dır), hanehalkı kişi sayısının (özellikle çocuk sayısının) fazlalığ1, örneklemin \%89'unun ilkokul ve daha düşük eğitime sahip olması, işsizlik (\%65), asgari gelir seviyesinin altında (\%100) ve düzensiz (\%77) gelir, çocukların okula gidememesi ve çocuk işçiler olarak sıralanabilir. Tüm bu ayrıştırıcı etmenlere daha önce de belirtilen Profil 1 ve 2 grupları eklendiğinde dışlanma sorununun çok katmanlılığı ortaya çıkmaktadır. Nitekim Profil 2 diye adlandırılan; Şirindere'nin riskli alan ilan edilmesiyle terk edilen gecekondulara yerleşen, düzenli bir geliri ol(a)mayan ve oldukça düşük yaşam standartlarına sahip bireyler, yoksunlukları ve yoksullukları yüzünden hem diğer gecekondu sakinleri (Profil 1) hem de Çiğdem Mahallesi sakinleri tarafından sosyal ve mekânsal olarak dışlandıklarını belirtmektedirler. Özellikle Adıyaman kırsalından göç eden ve kente yeni gelmiş bu hane halklarının eğitim düzeyleri çok düşüktür ve bu nedenle istihdama erişimleri oldukça kısıtlıdır; eğitim düzeyinin düşmesi iş bulma ve yüksek gelir elde etme ihtimalini azaltmaktadır. Bu hane halklarının çocuklarının maddi yetersizlikler ve aile ekonomisine katkı nedeniyle iyi bir eğitimden mahrum ka-

\footnotetext{
${ }^{3}$ Bu makalenin alan çalışmasının tamamlanmasının ardından Ankara Büyükşehir Belediyesi, "Gümüşdere”, “Çaldă̆” ve "Şirindere” Kentsel Dönüşüm ve Gelişim çalışmalarına yeniden başlamıştır.
} 
lacağı, dolayısıyla birkaç kuşak daha emek piyasalarından dışlanacakları açıktır. Bu kısır döngünün kırılması için öncelikle sosyal hizmetlerin arzının niteliği ve niceliği iyileştirilmelidir.

1970'li yıllarda gecekondu yaparak alana yerleşen, görece diğer gecekondululardan daha düzenli gelire ve daha iyi yaşam koşuluna sahip Profil 1'deki bireyler mekânsal olarak izole edildiklerini belirtmektedir. Bu grubun uzlaştığ 1 esas sorun kentten "fiziksel ayrışma" üzerinedir ki yaşadıkları kent sınıfsal bölünmelerle sınırlarını keskinleştirmiş durumdadır ve bu noktada onlar sınıf-altı olarak çöküntü alanlarında, varoşlarda barınmaktadırlar. Bu grubun uzlaşamadığı ikincil sorun ise "sosyal dışlanma" üzerinedir. Nitekim bireylerin bir kısmı (özellikle kadınlar ve çocuklar) Çiğdem Mahallesi sakinleri tarafından dışlandıklarını ifade ederken bir kısmı ise kendilerini sosyal olarak dışlanmış görmediklerini belirtmektedir. Aslında dişlanma, dışlayan ve dışlananların kentte karşı karşıya gelmesi, kesişimler yaşaması ile anlaşılabilmektedir. Ancak alanda çalışma, barınma, eğlenme, dinlenme gibi sosyal yaşam ve günlük rutinlerin mekânsal olarak tamamen farklılaşması (korunaklı kapalı siteler, özel eğitim ve sağlık tesisleri, kentin varsılları için planlanmış alışveriş ve eğlence merkezleri düşünüldügünde) bu kesişmeleri olanaksız kılmaktadır. Özellikle kadın ve çocukların yetişkin erkeklere nazaran dışlanma deneyimi yaşadıklarını belirtmeleri, onların kısıtlı kamusal alanda (park alanı) daha çok vakit geçirmesi ile ilgilidir. Burada bulundukları sürece bakışlarla, davranışlarla ve konuşmalarla kente aidiyetleri sorgulanmaktadır.

Profil 1 ve Profil 2 içerisinde dışlanma sebebinin ekonomik yoksunluklardan kaynaklandığı; etnik azınlık, din, dil, ırk ve cinsiyet nedeniyle bir dışlanma yaşanmadığı yapılan görüşmelerde tespit edilmiştir. Bu durum gelecek dönemler için umut vericidir. Sosyal olarak dışlanmanın önlenebilmesi için ilgili literatür incelendiğinde birçok politik söylemde bulunmak mümkündür. Ancak bu durumla ilgili örneklemin düşünceleri sorulduğunda, bu bireyler sosyal dışlanmanın önlenebilmesi için kendilerinin ve bakmakla yükümlü oldukları kişilerin ihtiyaçlarını karşılayabilecek düzenli bir işlerinin olmasının oldukça önemli olduğunu ifade etmektedir. İstihdama katılımla birlikte kendilerini toplumsal hayatın bir parçası olarak görecek ve özgüvenleri artacaktır.

Çalışmada son olarak dışlanma sorununun çok boyutlu yapısından hareketle dışlanan bireylerin kendileri arasında kolektif bir davranış biçimi geliştirip geliştirmediğinin değerlendirilebilmesi için örnekleme 
mahalleye yeni gelen ve kendilerinden daha düşük sosyo-ekonomik düzeydeki bireylere karşı tutumları sorulmuştur. Şaşırtıcıdır ki yeni gelen (gelecek olan) bu bireyleri dışlamayacakların belirtseler de görüşmelerde onlarla yaşamak istemedikleri sonucu ortaya çıkmıştır. Örneğin Profil 1'deki bireyler kendilerinden sonra gelenlerin (Profil 2) daha fazla suça karıştıklarını ve bu nedenle onlardan çekindiklerini, pek görüşmemeye çalıştıklarını ifade etmektedirler. Profil 2'deki bireyler ise daha önceki kötü deneyimleri nedeniyle Şirindere'de barınmaya çalışan az sayıdaki Suriyeli aileyi kendi aralarına almamaktadır. Zaten oldukça sınırlı olan emek piyasalarına Suriyelilerin girmesi onları oldukça huzursuz etmektedir. Farkında olmadan (ya da bilerek) bu iki grup kendilerinden farklı gördüklerini dişlanmaya devam etmektedir. Sebepler farklı olsa da dışlanma bağlamında durum Çiğdem Mahallesi sakinlerinin tutumlarıyla örtüşmektedir.

Çiğdem Mahallesi sakinleri yönünden Profil 1 ve Profil 2 grubu arasinda herhangi bir farklılık bulunmamaktadır. Her iki grup da kentin çöküntü alanlarında yaşayan, güvenlik açısından endişe duyulan ve yaşadıkları gecekonduların boşaltılarak dönüştürülmesi (benim gibileştirme çabası) istenen toplumun ötekileridir. Bu yenileme, yerinden etme yaklaşımı Ankara'da yapılan birçok kentsel dönüşüm uygulamasında benimsenmiş, gecekondu sahipleri ve (özellikle) kiracılar şehrin bir kıyısından başka bir kıyısına sürüklenerek yeni gettolar ortaya çıkarmıştır. Bu devinimde ise görüldüğü gibi her sosyal tabaka bir alttakini dışlama eğilimindedir. Hâlbuki sosyal dışlanmanın önlenmesi ve çöküntü alanlarındaki yaşam koşullarının iyileştirilebilmesi için öncelikle kentin yeni kaynaştırıcı mekânlara ve aktivitelere ihtiyacı bulunmaktadır. Bu noktada ise kent yöneticilerinin soylulaştırma, yerinden etme çalışmaları yerine sosyal, ekonomik, fiziksel ve politik önlemlere ve düzenlemelere ağırlık vererek toplumsal içerilmeyi sağlaması gerekmektedir. 


\title{
Extended Abstract
}

\section{Social Exclusion Experiences of Şirindere Gecekondu Residents}

\author{
Z. Asli Gurel Ucer \\ Seher Ozkazanc \\ Neslihan Kokol \\ Gazi University \\ N. Erbakan University \\ Gazi University
}

Since 1950s, especially in metropolitan cities, meeting the housing needs of individuals who migrate to cities has been one of the most important issues. The migrants struggle for space has resulted in formation of gecekondu areas, and they gain place in the city by this way. Gecekondu areas became the place of not only physical but also economic and social problems of the cities in time. Despite all the policies that have been implemented in Turkey for the last 50 years, gecekondu continued to be shelter for disadvantaged migrants. The struggle for gaining a place in the city transformed into a class struggle in time and the poor and deprived migrants have mostly been pushed out of social life. For more than half a century, the implementations to solve problems in the gecekondu areas mostly cover only physical interventions and the social and economic dimensions of the gecekondu are neglected. Thus, social exclusion arises which is defined as not being able to be included in the society, being isolated from social relationships and failure to completely integrate into the society.

Şirindere Gecekondu District is located in Çankaya District of Ankara, in the valley between METU and Çiğdem Neighborhood. The construction of first gecekondu's in the area started in 1970s. After construction of prestige / luxury houses near the valley, high-income citizens came to the area in 1990s. Sirindere Gecekondu District has been socially and spatially separated from the Çiğdem Neighborhood, the surrounding settlements and the whole city in the 2000s. The area was declared as an urban transformation area in 2005. Due to its geological risk, the decision was 
canceled and most of the owners left their houses. Then, new users started to live in the area. In 2017, the area again declared as a urban transformation area. The aim of this study is to state the social exclusion experiences of Şirindere Gecekondu District residents. In this context, this study presents development process of Şirindere Gecekondu District, and evaluates the socio-economic structure and problems of residents.

In-depth interviews with the households in Şirindere Gecekondu District, members of Çiğdemim Association and residents of Çiğdem Neighborhood and 30 household surveys with the Şirindere Gecekondu District residents are realized. The questionnaire includes 37 questions about demographic and household information, housing and living environment, working conditions and income level, immigration, education and health status, social perceptions and urban mobility. The presence of two different household profiles in Şirindere is determined. The first profile characterizes households, who settled in the area in 1970s, owners of their gecekondu and have more regular jobs and income, called Profile 1 in the study. The second profile characterizes households, who have migrated from Adiyaman in the last six years and relocated to the abandoned gecekondus and have no regular work and income, called Profile 2 in the study.

The findings of the survey are evaluated under 3 headings: Sociodemographic structure, working status and income level, living areas and urban services. Several factors -migration, young population, overpopulation of household, low level of education, high unemployment, informal employment, low and irregular income, indebtedness, nonattendance of children to school, child labour, etc.- have been identified that increase social fragility in the area. Also residents of Sirindere Gecekondu District cannot benefit from the opportunities provided by the city and therefore cannot be included in urban life.

The most important finding of the study was that the gecekondu residents who are living in this isolated area of the city also have socioeconomic varieties, and they also experience social exclusion among themselves. Social exclusion experience of Şirindere Gecekondu District residents can be summarized as follows: Çiğdem Neighborhood residants state that they do not cause social exclusion. However, they clearly state that they do not want to intersect with "others" in the urban service areas such as education, health, recreation and public spaces. The barbed 
wire between their houses and the gecekondu district is the most concrete form of this.

In terms of residents of Şirindere Gecekondu District (profile 1 and profile 2), the multiplicity of the exclusion problem arises. Profile 2, indicates that because of their deprivation and poverty they are socially and spatially excluded by both of the residents of Çiğdem Neighborhood and Profile 1. Profile 1, indicates that they are isolated spatially by the residents of Çiğdem Neighborhood. Exclusion becomes visible when groups intersect in collective spaces. However, the spatial differentiation of daily routines makes these intersections impossible. Women and children in profile 1 stated that they experience social exclusion because they spent more time in the limited public space.

Urban transformation process in the area will start new problems in terms of residents of Şirindere Gecekondu District. Those who live in gecekondu areas are the 'others' of the society who are asked to leave their homes in transformation processes. This renewal approach was adopted in many urban transformation practices in Ankara, where gecekondu owners and mostly tenants were dragged from one side of the city to another, and created new gecekondu areas. As can be seen in this movement, every social layer tends to exclude a subset. However, in order to prevent social exclusion and to improve living conditions in these areas the city needs new common spaces and activities to combine social groups. At this point, instead of gentrification and displacement, city administrators should prevent social exclusion and provide social inclusion by focusing on social, economic, physical and political interventions and regulations.

\section{Kaynakça/References}

Ataöv, A., Osmay, S. (2007). Türkiye'de kentsel dönüşüme yöntemsel bir yaklaşım. METU JFA, 2, 57.

Erman, T. (2004). Gecekondu çalışmalarında öteki olarak gecekondulu kurguları. European Journal of Turkish Studies. Social Sciences on Contemporary Turkey, 1.

Geniş, Ş. (2007). Küreselleşme, toplumsal eşitsizlik ve mekânsal ayrışma. Sivil Toplum, 5(17-18), 69-84.

Özkazanç, S. (2016). Kentsel ulaşım ve sosyal dışlanma ilişkisinin değerlendirilmesi: Ankara örneği, Yayınlanmamış doktora tezi, Gazi Üniversitesi Fen Bilimleri Enstitüsü, Ankara.

Sapancalı, F. (2005). Sosyal dışlanma, Dokuz Eylül Üniversitesi Yayınları, İzmir. 
Seviğ, V. (2016). Çiğdemim: Bir sivil toplum örgütünün 20 yıllık başarı öyküsü, Çiğdemim Derneği Yayınları:2, Ankara.

Silver, H. (1994). Social exclusion and social solidarity: three paradigms. Int'l Lab. Rev., 133, 531.

Dr. Z. Aslı Gürel Üçer, Gazi Üniversitesi Şehir ve Bölge Planlama Bölümü'nü 1998 yılında bitirdi. 2002 yılında Orta Doğu Teknik Üniversitesi Kentsel Politika Planlaması ve Yerel Yönetimler Anabilim Dalı'ndan yüksek lisans ve 2009 yılında Gazi Üniversitesi Şehir ve Bölge Planlama Anabilim Dalı'ndan doktora derecesini aldı. Halen Gazi Üniversitesi Şehir ve Bölge Planlama Bölümünde öğretim görevlisidir. Kentsel politikalar, kent yönetimi, kentsel yaşam kalitesi ve kentsel hizmetler konularında çalışmaları bulunmaktadır.

Dr. Z. Aslı Gurel Ucer, graduated from the Department of City and Regional Planning at Gazi University in 1998. She received her M.S. degree from the Urban Policy Planning and Local Governments graduate program at METU in 2002 and her Ph.D. degree from the Department of City and Regional Planning at Gazi University in 2009. She is currently working as an instructor at Gazi University, Faculty of Architecture, Department of City and Regional Planning. Her main research interests are Urban policies, urban management, urban quality of life and urban services.

E-mail: asligurelucer@gmail.com

Dr. Seher Özkazanç, Gazi Üniversitesi Mimarlık Fakültesi Şehir ve Bölge Planlama Bölümü'nü 2004 yılında bitirdi. Gazi Üniversitesi Fen Bilimleri Enstitüsü Şehir ve Bölge Planlama Anabilim Dalı'nda 2008 yılında yüksek lisans, 2016 yılında doktora derecesi aldı. 2006-2016 yılları arasında Gazi Şehir ve Bölge Planlama Bölümü'nde, 2016-2017 yılları arasında Yüzüncü Yıl Üniversitesi Şehir ve Bölge Planlama Bölümü'nde Araştırma Görevlisi, 2017 yılından itibaren ise Necmettin Erbakan Üniversitesi Şehir ve Bölge Planlama Bölümü'nde Dr. Öğretim Üyesi olarak görev yapmaktadır. Başlıca çalışma alanları ulaşım planlaması, kent sosyolojisi ve dezavantajlı gruplar için planlamadır.

Dr. Seher Ozkazanc, Graduated from the Department of Urban and Regional Planning at the Faculty of Architecture at Gazi University in 2004. Received a master's degree in 2008 and a doctoral degree in 2016 from the Department of Urban and Regional Planning at the Institute of Sciences at Gazi University. Worked as a research assistant at the Department of Urban and Regional Planning at Gazi University in the period of 2006-2016 and at the Department of Urban and Regional Planning at Yüzüncü Yıl University in the period of 2016-2017. Has been working as an Assistant Professor at the Department of Urban and Regional Planning at Necmettin Erbakan University since 2017. 
Main fields of research are transportation planning, urban sociology and planning for disadvantaged groups.

E-mail: seherpolat7@gmail.com

Neslihan Kokol, Gazi Üniversitesi Mimarlık Fakültesi Şehir ve Bölge Planlama Bölümü'nden 2017 yılında mezun olmuştur. 2015-2017 yılları arasında Gazi Üniversitesi Kentiçi Ulaşım Teknolojileri Erişebilirlik Uygulama ve Araştırma Merkezi'nde (KUTEM) öğrenci araştırmacı olarak çalıştı. 2017 yılından itibaren ise özel bir planlama bürosunda Şehir Plancısı olarak çalışmaktadır.

Neslihan Kokol, graduated from the Department of Urban and Regional Planning at the Faculty of Architecture at Gazi University in 2017. She worked as a research assistant at the Urban Transportation Technology Accessibility Implementation and Research Center (KUTEM) at Gazi University in the period of 2015-2017. She has been working as an Urban Planner at a private planning office since 2017.

E-mail: neslihankokol@gmail.com

\section{Kaynakça Bilgisi / Citation Information}

Z. Aslı Gürel Üçer, Z.A., Özkazanç, S. ve Kokol, N. (2018). Şirindere Gecekondu Sakinlerinin Sosyal Dışlanma Deneyimleri. IDEALKENT - Kent Araştırmaları Dergisi, 25, 834-855. 